\title{
Comparison of proton-specific ATPase activities in plume and root tissues of two co-occurring hydrocarbon seep tubeworm species Lamellibrachia luymesi and Seepiophila jonesi
}

\author{
Sharmishtha Dattagupta $\cdot$ Meredith Redding • \\ Kathryn Luley $\cdot$ Charles Fisher
}

Received: 21 April 2008 / Accepted: 8 January 2009 / Published online: 31 January 2009

(C) Springer-Verlag 2009

\begin{abstract}
Lamellibrachia luymesi and Seepiophila jonesi are co-occurring species of vestimentiferan tubeworms found at hydrocarbon seepage sites on the upper Louisiana slope of the Gulf of Mexico. Like all vestimentiferans, they rely on internal sulfide-oxidizing symbiotic bacteria for nutrition. These symbionts produce hydrogen ions as a byproduct of sulfide oxidation, which the host tubeworm needs to eliminate to prevent acidosis. The hydrothermal vent tubeworm Riftia pachyptila uses a high activity of $\mathrm{P}$ - and V-type $\mathrm{H}^{+}$-ATPases located in its plume epithelium to excrete protons. Unlike $R$. pachyptila, the seep species grow a posterior root, which they can use in addition to their plumes as a nutrient exchange surface. In this study we measured the ATPase activities of plume and root tissues collected from L. luymesi and S. jonesi, and used a combination of inhibitors to determine the relative activities of P- and V-type $\mathrm{H}^{+}$-ATPases. We found that the total $\mathrm{H}^{+}$-ATPase activity of their plumes was approximately $14 \mu \mathrm{mol} \mathrm{h}^{-1} \mathrm{~g}^{-1}$ wet weight, and that of their roots was between 5 and $7 \mu \mathrm{mol} \mathrm{h}^{-1} \mathrm{~g}^{-1}$ wet weight. These activities were more than ten times lower than those measured in $R$. pachyptila. We suggest that seep tubeworms might use passive channels to eliminate protons across their roots, in
\end{abstract}

Communicated by M. Kühl.

S. Dattagupta $(\bowtie) \cdot$ M. Redding $\cdot$ K. Luley $\cdot$ C. Fisher

Department of Biology, The Pennsylvania State University,

University Park, PA 16802, USA

e-mail: sdattag@uni-goettingen.de

Present Address:

S. Dattagupta

Courant Research Centre Geobiology,

Georg- August- Universität Göttingen,

370077 Göttingen, Germany addition to ATP-dependant proton pumps located in their plumes and roots. In addition, we found strong differences between the types of ATPase activities in the plumes of L. luymesi and $S$. jonesi. While the $\mathrm{H}^{+}$-ATPase activity of L. luymesi plumes is dominated by P-type ATPases, $S$. jonesi has an unusually high activity of V-type $\mathrm{H}^{+}$-ATPases. We suggest that $S$. jonesi relies on its high $\mathrm{V}$-type $\mathrm{H}^{+}$ATPase activity to drive carbon dioxide uptake across its plume surface. L. luymesi, on the other hand, might rely partially on bicarbonate uptake across its root.

\section{Introduction}

All living organisms maintain ionic homeostasis using membrane transport processes. Transport ATPases, which couple the energy derived from ATP hydrolysis to drive transport of solutes against their electrochemical gradients, are a ubiquitous type of membrane transport protein (Pedersen 1982). They are generally of three different categories: P-, V-, and F-type ATPases (Van Winkle 1999). P-type ATPases, named so because they are temporarily phosphorylated during their transport cycle, mediate transport of several different inorganic ions, including sodium, potassium, hydrogen, and calcium ions (Møller et al. 1996). The plasma membrane $\mathrm{Na}^{+} / \mathrm{K}^{+}$-ATPase is an example of a P-type ATPase. F- and V-type ATPases have multiple domains, and nearly all of them transport protons (Nelson 1992). In multicellular organisms, V-type ATPases are usually found in endomembranes and plasma membranes, whereas F-type ATPases are typically located in inner mitochondrial or thylakoid membranes (Bowman et al. 1988; Wieczorek et al. 2000).

Compared to other marine invertebrates, the hydrothermal vent vestimentiferan tubeworm Riftia pachyptila 
(Phylum Annelida, Class Polychaete, Family Siboglinidae) has unusually high ATPase activity, with a large proportion of its ATPases being P- and V-type ATPases devoted to proton transport (Goffredi and Childress 2001). R. pachyptila obtains sulfide, carbon dioxide, and oxygen from its environment and supplies them to internal sulfide-oxidizing bacterial symbionts, which it relies on for nutrition (Childress et al. 1984, 1991; Arp et al. 1985). The symbionts produce sulfate and hydrogen ions as end products of sulfide oxidation (Childress et al. 1984, 1991; Childress and Fisher 1992). $R$. pachyptila uses its highly vascularized plume for sulfide uptake, as well as sulfate and proton elimination (Arp et al. 1985; Goffredi et al. 1998). Since electrochemical gradients are unfavorable for both sulfate and proton elimination across the plume into the surrounding seawater, $R$. pachyptila expends a substantial amount of energy for eliminating these ions, and uses the high concentration of proton-specific ATPases located on its plume for proton excretion (Goffredi et al. 1998; Goffredi and Childress 2001; Girguis et al. 2002).

The vestimentiferans Lamellibrachia luymesi and Seepiophila jonesi normally co-exist in aggregations at hydrocarbon seep sites in the Gulf of Mexico (Bergquist et al. 2002). Unlike $R$. pachyptila, L. luymesi and S. jonesi grow root-like posterior extensions of their body, which they could potentially use as a metabolite-exchange surface in addition to their plume. To date, most physiological studies on hydrocarbon seep tubeworms from the Gulf of Mexico have focused on L. luymesi. These studies have established that $L$. luymesi uses its roots for sulfide uptake, as well as for elimination of sulfate and hydrogen ions (Julian et al. 1999; Freytag et al. 2001; Dattagupta et al. 2006). Although knowledge about $S$. jonesi's physiology is limited, circumstantial evidence suggests that relative to L. luymesi, it might rely more on its plume than its root for metabolite-exchange. While adult L. luymesi plumes are often over a meter above the sediment surface, where sulfide levels are undetectable (lower than $0.1 \mu \mathrm{M}$ ), adult $S$. jonesi plumes are normally close to the sediment surface where sulfide at low micromolar levels can often be detected (Freytag et al. 2001; Bergquist et al. 2003). Since $S$. jonesi hemoglobins have substantially higher affinity for sulfide than $L$. luymesi hemoglobins, $S$. jonesi could potentially acquire a substantial proportion of its sulfide across its plume (Freytag et al. 2003). Moreover, the chitin tubes surrounding $S$. jonesi roots are significantly less permeable than those of $L$. luymesi (K.E. Luley, unpublished data), suggesting that $S$. jonesi might not rely on its root as a significant metabolite-exchange surface.

In this study, we characterized the in vitro ATPase activities of plume and root tissues collected from L. luymesi and $S$. jonesi. Using inhibitors that target specific types of ATPases, we estimated the proton-specific ATPase activities of these tissues. In a sequential series of experiments, we used ouabagenin to inhibit $\mathrm{Na}^{+} / \mathrm{K}^{+}$-ATPases, vanadate to inhibit P-type ATPases, $N$-ethylmaleimide to inhibit $\mathrm{P}$ - and V-type ATPases, azide to inhibit F-type ATPases, and bafilomycin to inhibit V-type ATPases (Bowman et al. 1988; Lin and Randall 1993; Goffredi and Childress 2001). Based on the hypothesis that $S$. jonesi relies more heavily on its plume as a metabolite-exchange surface than L. luym$e s i$, we predicted lower proton-specific ATPase activities in L. luymesi plumes than $S$. jonesi plumes. Moreover, roots of $L$. luymesi and $S$. jonesi are buried in sediment where microbial sulfate reduction depletes protons, and calculations based on electrochemical gradients suggest that these tubeworms could use passive proton transport across their roots instead of ATPase mediated proton transport (Arvidson et al. 2004; Dattagupta et al. 2006). Based on this, we predicted relatively low proton-specific ATPase activities in L. luymesi and $S$. jonesi root tissues.

\section{Materials and methods}

\section{Collection of tissues for analysis}

L. luymesi and $S$. jonesi were collected from a site in the Mineral Management Service lease block GC234, located at a depth of approximately $540 \mathrm{~m}$ on the upper Louisiana slope of the Gulf of Mexico $\left(27^{\circ} 44.7^{\prime} \mathrm{N}, 91^{\circ} 13.3^{\prime} \mathrm{W}\right.$; MacDonald et al. 1990), using the robotic manipulator of the Johnson Sea-Link submersible. The tubeworms were transported to the surface in a temperature-insulating box, and maintained in cold seawater for $2-3 \mathrm{~h}$ prior to dissection. Plume and root tissues (not separated from trophosome) were obtained and frozen using liquid nitrogen within $30 \mathrm{~min}$ after the dissection was complete. They were transported in liquid nitrogen to the laboratory at Penn State University, where they were kept frozen at $-70^{\circ} \mathrm{C}$ until further analysis.

Preparation of tissue homogenates

Homogenization and subsequent ATPase assays were performed using modifications of procedures described previously (Lin and Randall 1993; Goffredi and Childress 2001). Frozen tissues were thawed on ice. Plumes were dissected to separate gill tissue from obturaculum, and root body wall was carefully separated from trophosome. The tissues were weighed and then homogenized on ice in $30 \mu \mathrm{mg}^{-1}$ of tissue homogenization buffer to make a crude homogenate (hereafter designated ' $\mathrm{C}$ '). Gill tissue was homogenized using a mechanical tissue homogenizer (Polytron PT 3,000, Brinkmann Instruments, Inc.), whereas root wall was homogenized using a Pyrex glass homogenizer. The 
homogenization buffer ( $\mathrm{pH}$ adjusted to 7.3) contained $50 \mathrm{mM}$ imidazole hydrochloride, $20 \mathrm{mM}$ ethylenediamine tetraacetic acid (EDTA), $300 \mathrm{mM}$ sucrose, $0.2 \mathrm{mM}$ phenylmethylsulfonyl fluoride (PMSF), $1 \mathrm{mM}$ dithiothreitol (DTT), and $5 \mathrm{mM} \beta$-mercaptoethanol (bME) (Goffredi and Childress 2001). A $50 \mu \mathrm{l}$ aliquot of the crude homogenate was stored at $-70^{\circ} \mathrm{C}$ until it was used for ATPase assays, and the remaining homogenate was centrifuged at $2,000 \mathrm{~g}$ for $7 \mathrm{~min}$, with the intention of enriching mitochondria in the supernatant, and the cell membrane fraction in the pellet (Lin and Randall 1993). The supernatant (hereafter designated 'S1') was stored at $-70^{\circ} \mathrm{C}$ until further analysis. The pellet was dissolved in $10 \times$ volume homogenization buffer containing 6\% 3-[(3-Cholamidopropyl)dimethylammonio]-1-propanesulfonate (CHAPS) zwitterionic detergent, in order to solubilize membrane proteins. It was then centrifuged at 2,000 g for another $7 \mathrm{~min}$, to enrich cell membrane proteins in the supernatant, and cell debris in the pellet (Lin and Randall 1993). The supernatant (S2) was divided into $100 \mu \mathrm{l}$ aliquots and stored at $-70^{\circ} \mathrm{C}$ until it was used for ATPase assays.

Determination of mitochondrial content: succinate dehydrogenase activity

The activity of the mitochondrial marker enzyme succinate dehydrogenase (SDH) was determined in homogenate fractions $\mathrm{C}, \mathrm{S} 1$, and $\mathrm{S} 2$ as previously described (Munujos et al. 1993). This assay is based on the conversion of 2-(4-iodophenyl)-3-(4-nitrophenyl)-5-phenyltetrazolium chloride (INT), a colorless compound, to formazan, a blue compound with a light absorption peak at $500 \mathrm{~nm}$. To perform the assay, $10 \mu \mathrm{l}$ of the homogenate was mixed with $990 \mu \mathrm{l}$ of the assay buffer (pH adjusted to 8.3) that contained $100 \mathrm{mM}$ Tris hydrochloride, $0.5 \mathrm{mM}$ EDTA, $2 \mathrm{mM}$ potassium cyanide, $2 \mathrm{mM}$ INT, $20 \mathrm{mM}$ succinate ( $\mathrm{pH}$ adjusted to 7.4 before it was added to the assay medium), and $12 \mathrm{~g} / \mathrm{l} \mathrm{crem-}$ ophor EL. Absorbance at $500 \mathrm{~nm}$ was measured every $30 \mathrm{~s}$ for $6 \mathrm{~min}$, and the mitochondrial activity was determined by subtracting absorbance of a control containing all assay components except for succinate.

Determination of plasma membrane content in fractions: $\mathrm{Na}^{+} / \mathrm{K}^{+}$-ATPase activity

The activity of the plasma membrane marker enzyme $\mathrm{Na}^{+}$/ $\mathrm{K}^{+}$-ATPase was determined in fractions $\mathrm{C}, \mathrm{S} 1$, and $\mathrm{S} 2 . \mathrm{Na}^{+}$/ $\mathrm{K}^{+}$-ATPase activity of fractions is usually estimated by determining ouabain-sensitive ATPase activity (Furriel et al. 2001). However, $\mathrm{Na}^{+} / \mathrm{K}^{+}$-ATPases of vestimentiferan tubeworms appear to be insensitive to oubain, but sensitive to its analogue, ouabagenin (Goffredi and Childress 2001). Therefore, we estimated $\mathrm{Na}^{+} / \mathrm{K}^{+}$-ATPase activity of fractions by determining ouabagenin-sensitive ATPase activity using the methodology described below.

\section{Measurement of ATPase activity}

ATPase activity was determined by spectrophotometric assay that uses a coupled pyruvate kinase/lactate dehydrogenase enzyme reaction (Lin and Randall 1993; Goffredi and Childress 2001). The assay medium ( $\mathrm{pH} 7.3$ ) was prepared fresh daily and contained $50 \mu \mathrm{M}$ fructose diphosphate, $2 \mathrm{mM}$ phosphoenol pyruvate (PEP), $3 \mathrm{mM}$ adenosine- 5 '-triphosphate (ATP), $0.2 \mathrm{mM}$ reduced $\beta$-nicotinamide adenine dinucleotide (NADH), 12.7 units/ $\mu$ lactate dehydrogenase, and 15 units/ $\mu 1$ pyruvate kinase, made in a stock solution containing $100 \mathrm{mM}$ sodium chloride, $20 \mathrm{mM}$ potassium chloride, $5 \mathrm{mM}$ magnesium chloride, $30 \mathrm{mM}$ imidazole, and $0.5 \mathrm{mM}$ ethylene glycol bis-(2-aminoethyl ether)- $N, N, N^{\prime} N^{\prime}$-tetraacetic acid (EGTA). One hundred microliters of the tissue homogenate was mixed with $900 \mu \mathrm{l}$ of assay medium and readings were taken at $340 \mathrm{~nm}$ every $30 \mathrm{~s}$ over a period of 5-10 min using a Beckman DU64 spectrophotometer (Beckman Coulter Inc., Fullerton, CA, USA), equipped with a temperature controlled cuvette $\left(15^{\circ} \mathrm{C}\right)$. Protein content of the homogenates was determined using the Bradford method, using a $1 \mathrm{mg} / \mathrm{ml}$ bovine serum albumin (BSA) standard prepared in the homogenization buffer. ATPase activity was expressed in either proteinspecific inorganic phosphate values $\left(\mu \mathrm{mol} \mathrm{P}_{\mathrm{i}} \mathrm{h}^{-1} \mathrm{mg}^{-1}\right.$ protein) or tissue wet weight specific values $\left(\mu \mathrm{mol} \mathrm{P}_{\mathrm{i}} \mathrm{h}^{-1} \mathrm{~g}^{-1}\right.$ wet weight).

Inhibitor exposure

Tissue homogenates were incubated with various ATPasespecific inhibitors before the assay was conducted. Fifty microliters of a stock solution of an inhibitor (or solvent, in the case of controls) was mixed with $50 \mu \mathrm{l}$ of the tissue homogenate. The mixture was incubated at room temperature for a period of $2 \mathrm{~h}$, with the exception of Bafilomycin, which was incubated for $30 \mathrm{~min}$ (Goffredi and Childress 2001). The inhibitor stock solutions were: $20 \mathrm{mM}$ sodium azide, $40 \mathrm{mM}$ ouabagenin, $20 \mathrm{mM}$ NEM, $20 \mathrm{mM}$ vanadate, and $7 \mu \mathrm{M}$ bafolimycin. Bafilomycin stock solution was made using 5\% DMSO as solvent, and corresponding controls contained the same amount of DMSO. All other inhibitor solutions were made using water. Azide, vanadate, and bafolimycin stock solutions were made in advance and the first two were stored at room temperature, whereas bafilomycin was stored at $-20^{\circ} \mathrm{C}$. The vanadate stock solution was monitored at $400 \mathrm{~nm}$ to ensure that decameric vanadium species were negligible or absent in the solution (Aureliano and Gândara 2005).The NEM stock solution was made fresh daily. 
Estimation of proton-specific P- and V-type ATPase activities

Inhibitor sensitivity was used to estimate proton-specific ATPase activities as described below. At the concentrations used in our assays, NEM inhibits both P- and V-type ATPases (Pedersen and Carafoli 1987; Forgac 1989). Since vanadate sensitivity was found to be low in most tissues examined, NEM-sensitivity was used to estimate the total P- and V-type ATPase activity. Bafilomycin-sensitivity was used to estimate V-type ATPase activity, as it is extremely specific to V-type ATPases at concentrations used in our experiments (Bowman et al. 1988). Since EGTA, a $\mathrm{Ca}^{2+}$ chelator was used in our assays, $\mathrm{Ca}^{2+}$-ATPase activity was assumed to be negligible (Lin and Randall 1993; Goffredi and Childress 2001). Total P-type ATPase activity, which includes $\mathrm{Na}^{+} / \mathrm{K}^{+}$-ATPases, and $\mathrm{H}^{+}$-ATPases, was estimated by subtracting bafilomycin-sensitive activity from NEMsensitive activity. Finally, P-type $\mathrm{H}^{+}$-ATPase activity was estimated by subtracting ouabagenin-sensitive $\mathrm{Na}^{+} / \mathrm{K}^{+}$ATPase activity from the total P-type ATPase activity.

\section{Results}

Mitochondrial activity of fractions

SDH activity, which was used to estimate mitochondrial content, was highest in the crude homogenates (C) of all tissues examined (Fig. 1). The S1 supernatant fraction contained between 26 and $77 \%$ of the total SDH activity, indicating substantial removal of mitochondria using the first centrifugation step. However, the fraction S2, which was subsequently used to analyze total ATPase activity, still showed some SDH activity. The S2 fractions of L. luymesi and $S$. jonesi plume tissues contained, respectively, 25 and $22 \%$ of the mitochondrial activity found in their respective crude homogenates. On the other hand, the S2 fractions of

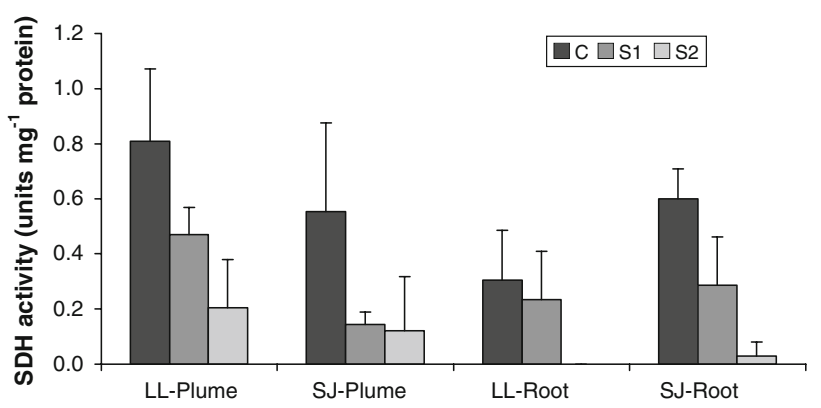

Fig. 1 Mean \pm standard deviation of succinate dehydrogenase (SDH) activity in the crude, $S 1$ and $S 2$ fractions of the various tissues analyzed ( $N=5$ for all tissues). $L L$ and $S J$ correspond to $L$. luymesi and $S$. jonesi, respectively
L. luymesi and S. jonesi root tissues contained, respectively, 0 and $5 \%$ of the total mitochondrial activity. Therefore, mitochondrial removal was more efficient in the root than the plume tissue homogenates.

$\mathrm{Na}^{+} / \mathrm{K}^{+}$-ATPase activity of fractions

Ouabagenin-sensitive activity of fractions, which was used to estimate activity of the plasma membrane marker enzyme $\mathrm{Na}^{+} / \mathrm{K}^{+}$-ATPase, indicated that the purification process was successful in enriching plasma membrane in the $\mathrm{S} 2$ fraction (Fig. 2). Using the mean values of the $\mathrm{Na}^{+} /$ $\mathrm{K}^{+}$-ATPase activities, we estimated that the enrichment of plasma membrane in the S2 fraction was 288 and $168 \%$, respectively, for L. luymesi plume and root tissues. Similarly, the enrichment was 159 and $125 \%$, respectively, for $S$. jonesi plume and root tissues.

\section{Total ATPase activities}

Total ATPase activity in $\mu \mathrm{mol} \mathrm{P}_{\mathrm{i}} \mathrm{h}^{-1} \mathrm{mg}^{-1}$ protein was similar in all tissues examined (Table 1; $P>0.05$; twosided $t$ test). However, both species had significantly higher protein content, i.e., mg protein per $\mathrm{g}$ tissue wet weight (WW), in plume than in root tissues $(P<0.0025$; two-sided $t$ tests). As a result, wet weight specific plume ATPase activities ( $\mu \mathrm{mol} \mathrm{P}_{\mathrm{i}} \mathrm{h}^{-1} \mathrm{~g}^{-1} \mathrm{WW}$ ) were significantly higher than root ATPase activities in both species. The average $S$. jonesi plume and root ATPase activities $\left(\mu \mathrm{mol} \mathrm{P}_{\mathrm{i}} \mathrm{h}^{-1} \mathrm{~g}^{-1}\right.$ WW) were higher than L. luymesi plume and root ATPase activities, but the differences were not significant (plume: $P=0.246$; root: $P=0.232$; two-sided $t$ tests).

Inhibitor sensitivities

Inhibitor studies were performed with L. luymesi and $S$. jonesi plume and root tissues, and comparisons were made between species and tissue types (Fig. 3). For L. luymesi,

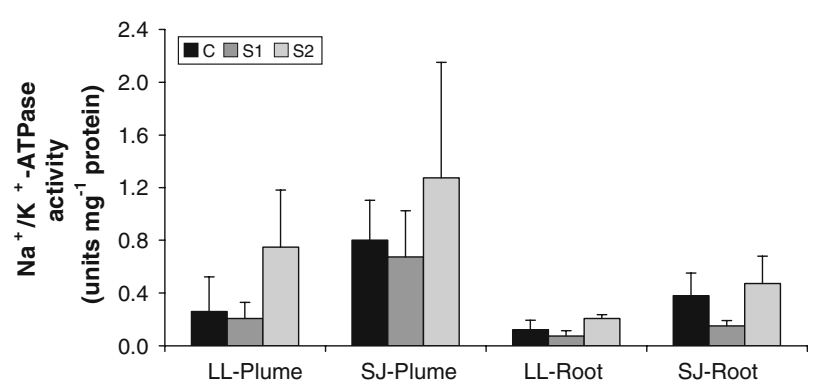

Fig. 2 Mean \pm standard deviation of $\mathrm{Na}^{+} / \mathrm{K}^{+}$-ATPase activity in the crude, $S 1$ and $S 2$ fractions of the various tissues analyzed $(N=4$ for plume tissues; $N=3$ for root tissues). $L L$ and $S J$ correspond to $L$. luymesi and $S$. jonesi, respectively 
Table 1 The total ATPase activity of various tissues examined in this study

\begin{tabular}{|c|c|c|c|c|}
\hline \multirow[t]{2}{*}{ Species } & \multicolumn{2}{|c|}{ Plume ATPase activity } & \multicolumn{2}{|c|}{ Root ATPase activity } \\
\hline & $\begin{array}{l}\mu \mathrm{mol} \mathrm{P}_{\mathrm{i}} \mathrm{h}^{-1} \mathrm{mg}^{-1} \\
\text { protein }\end{array}$ & $\begin{array}{l}\mu \mathrm{mol} \mathrm{P}_{\mathrm{i}} \mathrm{h}^{-1} \mathrm{~g}^{-1} \\
\mathrm{WW}\end{array}$ & $\begin{array}{l}\mu \mathrm{mol} \mathrm{P}_{\mathrm{i}} \mathrm{h}^{-1} \mathrm{mg}^{-1} \\
\text { protein }\end{array}$ & $\begin{array}{l}\mu \mathrm{mol} \mathrm{P} \mathrm{P}_{\mathrm{i}} \mathrm{h}^{-1} \mathrm{~g}^{-1} \\
\mathrm{WW}\end{array}$ \\
\hline L. luymesi $(N=15)$ & $2.8 \pm 1.3$ & $34.9 \pm 14.6$ & $2.6 \pm 1.4$ & $13.1 \pm 6.5$ \\
\hline S. jonesi $(N=12)$ & $2.0 \pm 0.6$ & $41.4 \pm 13.4$ & $2.5 \pm 0.7$ & $16.3 \pm 7.6$ \\
\hline
\end{tabular}

Fig. 3 Comparison of percent inhibition of total ATPase activity by various inhibitors in a L. luymesi plume and root tissues; $\mathbf{b}$ L. luymesi and $S$. jonesi plume tissues; c $S$. jonesi plume and root tissues; and $\mathbf{d}$ L. luymesi and $S$. jonesi root tissues. An asterisk implies a significant difference $(P<0.05$; two-sided $t$ test). $A Z$ azide, $O U$ ouabagenin, $N E M N$-ethylmaleimide, $V A N$ vanadate, $B A F$ bafilomycin. Percent inhibition is expressed with respect to baseline activity measured in the presence of the solvent used to make inhibitor solutions
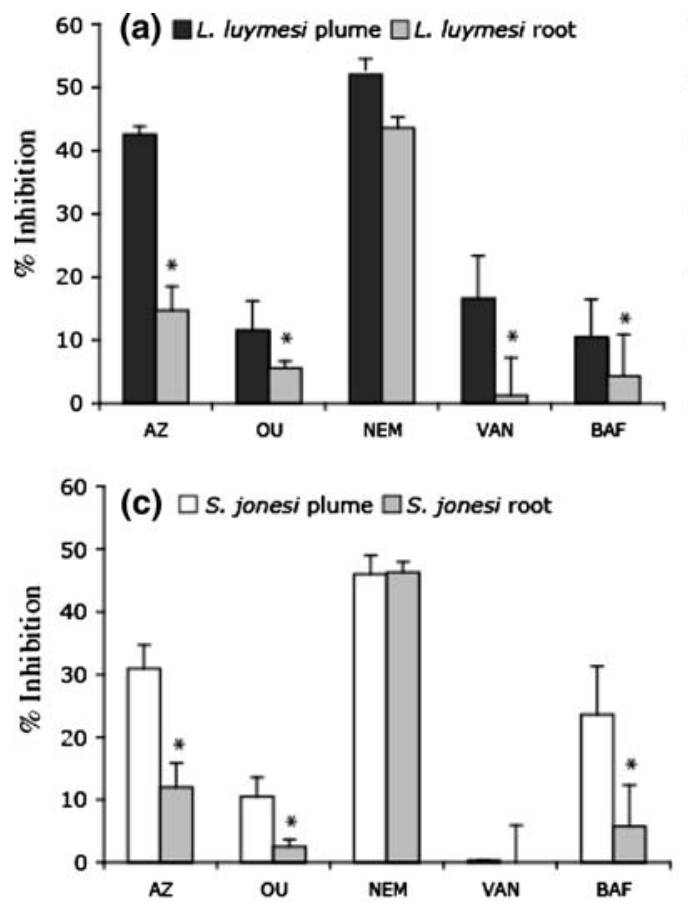

(b) $\square$ L. luymesi plume $\square$ s. jonesi plume

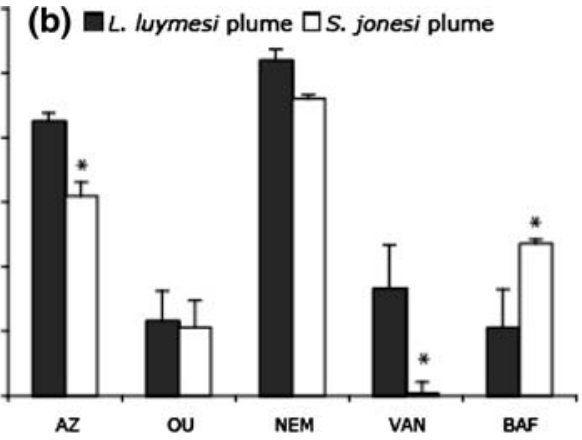

(d) $\square$ L. luymesi root $\square$ s. jonesi root

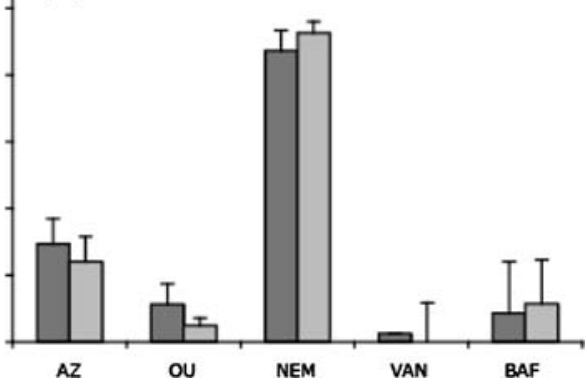

percent inhibition by all inhibitors was higher for plume than for root tissues, and this difference was significant $(P<0.05$; two-sided $t$ test) for all inhibitors except NEM. Similarly, percent inhibition by azide, ouabagenin, and bafilomycin were significantly higher for $S$. jonesi plume than for root tissues. The higher inhibition by azide in plume tissues of both species was consistent with the higher mitochondrial content found in their S2 fractions (Fig. 1). L. luymesi and $S$. jonesi root tissues were very similar with respect to inhibition by all compounds tested, whereas there were some notable differences between their plume tissues. While azide and vanadate inhibition were significantly higher for L. luymesi plume tissue, bafilomycin inhibition was significantly higher for $S$. jonesi plume tissue. Except for L. luymesi plume tissue, all other tissues appeared to be insensitive to vanadate inhibition.

We calculated activities of the $\mathrm{V}$ - and the P-type $\mathrm{H}^{+}$ATPase for the root and plume tissues of both species based on the results from the inhibitor experiments (Table 2). Although the total ATPase activity is very similar for a given tissue between species, the contribution of $\mathrm{V}$ - and $\mathrm{P}$-type is very different in the plumes. Most of the activity in
S. jonesi plume is due to $\mathrm{V}$-type $\mathrm{H}^{+}$-ATPase while most of the activity in L. luymesi plume is due to P-type $\mathrm{H}^{+}$-ATPase.

\section{Discussion}

Seep tubeworms have much lower ATPase activities than $R$. pachyptila

R. pachyptila, the vestimentiferan tubeworm found at hydrothermal vent sites on the East Pacific Rise, has protein-specific ATPase activities that are approximately four times higher than that of other marine invertebrates that do not harbor symbionts (Goffredi and Childress 2001). Using an inhibitor study similar to ours, the authors concluded that a majority of $R$. pachyptila's ATPase activity was used for elimination of protons produced by its symbionts during sulfide oxidation. In contrast, we found that the proteinspecific ATPase activities of the two hydrocarbon seep tubeworm species, L. luymesi and S. jonesi, were similar to that of non-symbiotic, shallow-living marine invertebrates investigated by Goffredi and Childress (2001). 
Table 2 Estimated P- and V-type ATPase activities (in $\mu \mathrm{mol} \mathrm{P}_{\mathrm{i}} \mathrm{h}^{-1} \mathrm{~g}^{-1}$ tissue wet weight) of $L$. luymesi plume (LP), L. luymesi root (LR), S. jonesi plume (SP), and $S$. jonesi root (SR)

Proton-specific ATPase activities are in bold

\begin{tabular}{|c|c|c|c|c|c|}
\hline \multirow[t]{2}{*}{ ATPase type } & \multirow[t]{2}{*}{ Inhibitor sensitivity } & \multicolumn{4}{|c|}{$\begin{array}{l}\text { ATPase activity } \\
\left(\mu \mathrm{mol} \mathrm{P}_{\mathrm{i}} \mathrm{h}^{-1} \mathrm{~g}^{-1} \mathrm{WW}\right)\end{array}$} \\
\hline & & LP & LR & $\mathrm{SP}$ & $\mathrm{SR}$ \\
\hline Total & None & 35.0 & 13.1 & 41.4 & 16.3 \\
\hline Total P- and V-type ATPase & NEM & 18.2 & 5.8 & 19.0 & 7.5 \\
\hline V-type $\mathrm{H}^{+}$ATPase & Bafilomycin & 3.7 & 0.6 & 9.8 & $\mathbf{0 . 9}$ \\
\hline Total P-type ATPase & NEM- (Bafilomycin) & 14.5 & 5.2 & 9.3 & 6.6 \\
\hline $\mathrm{Na}^{+} / \mathrm{K}^{+}$-ATPase & Ouabagenin & 4.1 & 0.7 & 4.3 & 0.4 \\
\hline P-type $\mathrm{H}^{+}$-ATPase & $\begin{array}{l}\text { NEM- (Bafilomycin + } \\
\text { Ouabagenin) }\end{array}$ & 10.5 & 4.5 & 4.9 & 6.2 \\
\hline
\end{tabular}

Like R. pachyptila, L. luymesi and S. jonesi have sulfide-oxidizing symbionts that produce protons as a byproduct of their metabolism. However, seep tubeworms have lower metabolic rates than $R$. pachyptila, which could explain the lower ATPase activities we measured. Alternately, seep tubeworms might rely on passive transport of waste ions such as sulfate and protons across their root surface (Dattagupta et al. 2006), diminishing their need for high tissue ATPase activities, as discussed below.

L. luymesi might use proton channels in its roots for proton elimination

An important distinction between $R$. pachyptila and the seep tubeworms we examined is the presence of posterior buried roots in the latter species. Both L. luymesi and $S$. jonesi have long posterior roots, but so far, the use of roots for metabolite-exchange has been better studied in L. luymesi than in S. jonesi. Based on electrochemical gradients, proton movement across L. luymesi's plume epithelium into the external seawater medium would require active transport, whereas it could occur passively across the root epithelium (Dattagupta et al. 2006). In this study, we found that L. luymesi plume tissue has a total $\mathrm{H}^{+}$ATPase activity of $14 \mu \mathrm{mol} \mathrm{P}_{\mathrm{i}} \mathrm{h}^{-1} \mathrm{~g}^{-1}$ wet weight, whereas its root tissue has an activity of only $5 \mu \mathrm{mol} \mathrm{P}_{\mathrm{i}} \mathrm{h}^{-1} \mathrm{~g}^{-1}$ wet weight (Table 2). Given the fact that L. luymesi eliminates a majority of its protons across its roots (Dattagupta et al. 2006), it appears that proton channels, rather than $\mathrm{H}^{+}$-ATPases might mediate proton transport across L. luymesi's root epithelium.

In laboratory experiments where L. luymesi and $R$. pachyptila were exposed to similar levels of external sulfide, L. luymesi's plume proton elimination rates were on average $11.9 \mu$ equivalents $\mathrm{g}^{-1} \mathrm{~h}^{-1}$, compared to $R$. pachyptila's elimination rate of $40.5 \mu$ equivalents $\mathrm{g}^{-1} \mathrm{~h}^{-1}$ (Girguis et al. 2002). Since L. luymesi eliminates approximately $67 \%$ of its protons across its roots (Dattagupta et al. 2006), the results of these studies indicate that the total proton elimination rate of $L$. luymesi is approximately $36 \mu$ equivalents $\mathrm{g}^{-1} \mathrm{~h}^{-1}$, slightly lower than the massspecific rate of $R$. pachyptila. However, the mass-specific $\mathrm{H}^{+}$-ATPase activity of L. luymesi is more than ten times lower than that of $R$. pachyptila. $R$. pachyptila has a plume P-type $\mathrm{H}^{+}$-ATPase activity of $136-174 \mu \mathrm{mol} \mathrm{P}_{\mathrm{i}} \mathrm{h}^{-1} \mathrm{~g}^{-1}$ wet weight and a V-type $\mathrm{H}^{+}$-ATPase activity of $80 \mu \mathrm{mol} \mathrm{P}_{\mathrm{i}}$ $\mathrm{h}^{-1} \mathrm{~g}^{-1}$ wet weight (Goffredi and Childress 2001). On the other hand, L. luymesi has a total (plume and root) P-type $\mathrm{H}^{+}$-ATPase activity of $15 \mu \mathrm{mol} \mathrm{P} \mathrm{P}_{\mathrm{i}} \mathrm{g}^{-1}$ wet weight and a V-type $\mathrm{H}^{+}$-ATPase activity of $4 \mu \mathrm{mol} \mathrm{P}_{\mathrm{i}} \mathrm{h}^{-1} \mathrm{~g}^{-1}$ wet weight (Table 2). The large discrepancy between these values is consistent with $L$. luymesi relying partly on passive proton channels for proton elimination across its root epithelium, in addition to $\mathrm{H}^{+}$-ATPases in its plume and root tissues.

The $\mathrm{pH}$ of $S$. jonesi body fluids is similar to that of L. luymesi (S. Dattagupta, unpublished data) and the two seep species commonly co-exist in aggregations (Bergquist et al. 2002). Since $S$. jonesi also has roots buried in sediments where pore water $\mathrm{pH}$ is depleted, it could potentially eliminate protons using passive transport across its roots. In this study, we found that its plume $\mathrm{H}^{+}$-ATPase activity was $14.7 \mu \mathrm{mol} \mathrm{P}_{\mathrm{i}} \mathrm{h}^{-1} \mathrm{~g}^{-1}$ wet weight, whereas its root $\mathrm{H}^{+}$-ATPase activity was $7.1 \mu \mathrm{mol} \mathrm{P}_{\mathrm{i}} \mathrm{h}^{-1} \mathrm{~g}^{-1}$ wet weight. While it appears likely that $S$. jonesi use their roots for passive proton transport, laboratory experiments that directly measure its proton elimination rates are necessary to substantiate this possibility.

The relative abundance of P- and V-type ATPases varies between seep species

Based on differences in growth habits of L. luymesi and $S$. jonesi, we predicted that $S$. jonesi would rely more on its plume for metabolite-exchange than L. luymesi does. Contrary to our expectations, we found very similar total plume $\mathrm{H}^{+}$-ATPase activities in the two tubeworm species. However, there were some interesting differences in the relative abundances of $\mathrm{P}$ - and $\mathrm{V}$-type $\mathrm{H}^{+}$-ATPases in these tissues. 
While $74 \%$ of the $\mathrm{H}^{+}$-ATPases in L. luymesi plume tissue were P-type ATPases, $66 \%$ of the $\mathrm{H}^{+}$-ATPases in $S$. jonesi plume tissue were V-type ATPases (Table 2).

$\mathrm{V}$-type $\mathrm{H}^{+}$-ATPases are important for creating proton gradients that drive secondary membrane transport across the plasma membranes of some invertebrates (Azuma and Ohta 1998; Wieczorek et al. 2000). In R. pachyptila, V-type ATPases are co-localized with the enzyme carbonic anhydrase on the apical region of the plume epithelium, and are thought to generate acidic extracellular $\mathrm{pH}$ conditions that facilitate $\mathrm{CO}_{2}$ uptake (De Cian et al. 2003). V-type $\mathrm{H}^{+}$ATPases represent on average $24 \%$ of the total ATPase activity in $S$. jonesi plume tissue (Fig. 3), whereas they represent only $14 \%$ of the total ATPase activity in $R$. pachyptila plumes (Goffredi and Childress 2001).

The unusually high abundance of $\mathrm{V}$-type $\mathrm{H}^{+}$-ATPases in the $S$. jonesi plume tissue might indicate that this tubeworm relies heavily on its plume for $\mathrm{CO}_{2}$ uptake. In contrast, Vtype $\mathrm{H}^{+}$-ATPases represent only $10 \%$ of the total ATPase activity in L. luymesi plume tissue (Fig. 3). A previous study suggested that L. luymesi might supplement plume $\mathrm{CO}_{2}$ uptake with $\mathrm{HCO}_{3}^{-}$uptake across their roots (Dattagupta et al. 2006). The results of this study are consistent with this possibility.

Possible caveats of this study and future directions

In this study, we used an in vitro approach in which we exposed tissue homogenates to various inhibitors to deduce membrane transport mechanisms. While inhibitors are powerful tools for arriving at mechanistic deductions, lack of inhibitor sensitivity does not indicate the absence of a target protein (Cabantchik and Greger 1992). Moreover, differences in purification efficacy of membrane fractions could lead to artifacts. In our study, we found plasma membrane purification efficiencies were slightly higher for L. luymesi tissues than S. jonesi tissues, which could lead us to underestimate $S$. jonesi ATPase activities. Our study provides the first clues to the membrane transport mechanisms used by seep tubeworms for proton elimination. Future studies using purified membrane vesicles, or tissue localization with specific antibodies (De Cian et al. 2003) could provide more conclusive evidence for the existence of specific membrane proteins such as proton channels in root tissues of seep tubeworms.

Acknowledgments We thank the captain and crew of the Research Vessel (RV) Seward Johnson II as well as the crew and pilots of the Johnson Sea-link submersible (Harbor Branch Oceanographic Institution). The Minerals Management Service, Gulf of Mexico Regional OCS office, through contract number 1435-01-96-CT30813, the NOAA National Undersea Research Program at the University of North Carolina, Wilmington, the NOAA Ocean Exploration Program, and the National Science Foundation grant OCE 0117050 supported this work. The experiments comply with the current laws of the country in which the experiments were performed. This is contribution number 15 from the Courant Research Centre Geobiology.

\section{References}

Arp AJ, Childress JJ, Fisher CR (1985) Blood gas transport in Riftia pachyptila. Bull Biol Soc Wash 6:289-300

Arvidson RS, Morse JW, Joye SB (2004) The sulfur biogeochemistry of chemosynthetic cold seep communities, gulf of Mexico, USA. Mar Chem 87:97-119. doi:10.1016/j.marchem.2003.11.004

Aureliano M, Gândara RMC (2005) Decavanadate effects in biological systems. J Inorg Biochem 99:979-985. doi:10.1016/j.jinorgbio. 2005.02.024

Azuma M, Ohta Y (1998) Changes in $\mathrm{H}^{+}$- translocating vacuolar-type ATPase in the anterior silk gland of Bombyx mori during metamorphosis. J Exp Biol 201:479-486

Bergquist DC, Urcuyo IA, Fisher CR (2002) Establishment and persistence of seep vestimentiferan aggregations on the upper Louisiana slope of the Gulf of Mexico. Mar Ecol Prog Ser 241:89-98. doi: $10.3354 /$ meps 241089

Bergquist DC, Andras JP, McNelis T, Howlett S, van Horn MJ (2003) Succession in upper Louisiana slope cold seep vestimentiferan aggregations: the importance of spatial variability. P.S.Z.N. Mar Ecol (Berl) 24:31-44. doi:10.1046/j.1439-0485.2003.03800.x

Bowman EJ, Siebers A, Alterndorf K (1988) Bafilomycins: a class of inhibitors of membrane ATPases from microorganisms, animal cells, and plant cells. Proc Natl Acad Sci USA 85:7972-7976. doi:10.1073/pnas.85.21.7972

Cabantchik ZI, Greger R (1992) Chemical probes for anion transporters of mammalian cell membranes. Am J Physiol Cell Physiol 262:C803-C827

Childress JJ, Fisher CR (1992) The biology of hydrothermal vent animals: physiology, biochemistry, and autotrophic symbioses. In: Barnes M, Ansell AD, Gibson RN (eds) Oceanogr Mar Biol Annu Rev. UCL Press, London, pp 337-441

Childress JJ, Arp AJ, Fisher CR (1984) Metabolic and blood characteristics of the hydrothermal vent tube-worm Riftia pachyptila. Mar Biol (Berl) 83:109-124. doi:10.1007/BF00394718

Childress JJ, Fisher CR, Favuzzi JA, Kochevar RE, Sanders NK, Alayse AM (1991) Sulfide-driven autotrophic balance in the bacterial symbiont-containing hydrothermal vent tubeworm, Riftia pachyptila Jones. Biol Bull 180:135-153. doi:10.2307/ 1542437

Dattagupta S, Miles LL, Barnabei MS, Fisher CR (2006) The hydrocarbon seep tubeworm Lamellibrachia luymesi primarily eliminates sulfate and hydrogen ions across its roots to conserve energy and ensure sulfide supply. J Exp Biol 209:3795-3805. doi:10.1242/jeb.02413

De Cian M-C, Bailly X, Morales J, Strub J-M, Van Dorsselaer A, Lallier FH (2003) Characterization of carbonic anhydrases from Riftia pachyptila, a symbiotic invertebrate from deep-sea hydrothermal vents. Proteins 51:327-339. doi:10.1002/prot.10295

Forgac M (1989) Structure and function of vacuolar class of ATP-driven proton pumps. Physiol Rev 69:765-796

Freytag JK, Girguis PR, Bergquist DC, Andras JP, Childress JJ, Fisher CR (2001) A paradox resolved: sulfide acquisition by roots of seep tubeworms sustains net chemoautotrophy. Proc Natl Acad Sci USA 98:13408-13413. doi:10.1073/pnas.231589498

Freytag JK, Smith RM, Breault SR, Hourdez SM, Jones CS, Fisher CR (2003) Sulfide binding properties of hemoglobins isolated from two species of cold seep vestimentiferans. Ph.D. Dissertation, Biology, University Park 
Furriel RPM, McNamara JC, Leone FA (2001) Nitrophenylphosphatase as a tool to characterize gill $\mathrm{Na}^{+}, \mathrm{K}^{+}$ATPase activity in hyperregulating Crustacea. Comp Biochem Physiol Part A 130:665-676. doi:10.1016/S1095-6433(01)00400-7

Girguis PR, Childress JJ, Freytag JK, Klose K, Stuber R (2002) Effects of metabolite uptake on proton-equivalent elimination by two species of deep-sea vestimentiferan tubeworm, Riftia pachyptila and Lamellibrachia luymesi : proton elimination is a necessary adaptation to sulfide-oxidizing chemoautotrophic symbionts. J Exp Biol 205:3055-3066

Goffredi SK, Childress JJ (2001) Activity and inhibitor sensitivity of ATPases in the hydrothermal vent tubeworm Riftia pachyptila: a comparative approach. Mar Biol (Berl) 138:259-265. doi:10.1007/ s002270000462

Goffredi SK, Childress JJ, Lallier FH, Desaulniers NT (1998) How to be the perfect host: $\mathrm{CO}_{2}$ and $\mathrm{HS}^{-}$accumulation and $\mathrm{H}^{+}$elimination in the hydrothermal vent tube-worm Riftia pachyptila. Cah Biol Mar 39:297-300

Julian D, Gaill F, Wood E, Arp A, Fisher C (1999) Roots as a site of hydrogen sulfide uptake in the hydrocarbon seep vestimentiferan Lamellibrachia sp. J Exp Biol 202:2245-2257

Lin H, Randall DJ (1993) $\mathrm{H}^{+}$-ATPase activity in crude homogenates of fish gill tissue: inhibitor sensitivity and environmental and hormonal regulation. J Exp Biol 180:163-174
MacDonald IR, Guinasso NL Jr, Reilly JF, Brooks JM, Callender WR, Gabrielle SG (1990) Gulf of Mexico hydrocarbon seep communities: VI. Patterns in community structure and habitat. Geo-Mar Lett 10:244-252. doi:10.1007/BF02431071

Møller JV, Juul B, leMaire M (1996) Structural organization, ion tranport, and energy transduction of P-type ATPases. Biochim Biophys Acta 1286:1-51

Munujos P, Coll-Canti J, Gonzalez-Sastre F, Javier Gella F (1993) Assay of succinate dehydrogenase activity by a colorimetric-continous method using iodonitrotetrazolium chloride as electron acceptor. Anal Biochem 212:506-509. doi:10.1006/abio.1993. 1360

Nelson N (1992) Evolution of organellar proton-ATPases. Biochim Biophys Acta 1100:109-124. doi:10.1016/0005-2728(92)90072-A

Pedersen PL (1982) $\mathrm{H}^{+}$-ATPases in biological systems: an overview of their function. The New York Academy of Sciences, New York

Pedersen PL, Carafoli E (1987) Ion motive ATPases. I. Ubiquity, properties and significance to cell function. Trends Biochem Sci 12:146-150. doi:10.1016/0968-0004(87)90071-5

Van Winkle LJ (1999) Biomembrane transport. Academic Press, San Diego

Wieczorek H, Gruber G, Harvey WR, Huss M, Merzendorfer H, Zeiske W (2000) Structure and regulation of insect plasma membrane $\mathrm{H}^{+}$V-ATPase. J Exp Biol 203:127-135 